\title{
Implant Disassembly Due to Pedicle Screw Nut Loosening
}

\author{
Prasad Krishnan ${ }^{10}$ Sayan Das ${ }^{2}$ \\ ${ }^{1}$ Department of Neurosurgery, National Neurosciences Centre, \\ Kolkata, West Bengal, India \\ 2 Department of Radiology, Peerless Hospital, Kolkata, West Bengal, \\ India
}

J Neurosci Rural Pract 2021;12:813-814.

Two male patients ( 45 years and 58 years old, respectively) underwent spinal decompression, intertransverse grafting and L4-5 fixation with pedicle screw and rod construct for L4-5 grade 1 spondylolisthesis with an uneventful postoperative outcome. Immediate postoperative $\mathrm{X}$-rays and those at 3 months were satisfactory. Follow-up imaging at 6 months in the first case ( - Fig. 1) showed that the inner nut of the left L4 screw had loosened off and moved out of the construct and was lying just medial to the pedicle screw head. However, the rod remained in position inside the screw head. In the second case, X-rays at 6 months (-Fig. 2) revealed that the right-sided rod had migrated medially out off the right L5 pedicle screw head, though in this case the inner nut was still in position. Both were offered

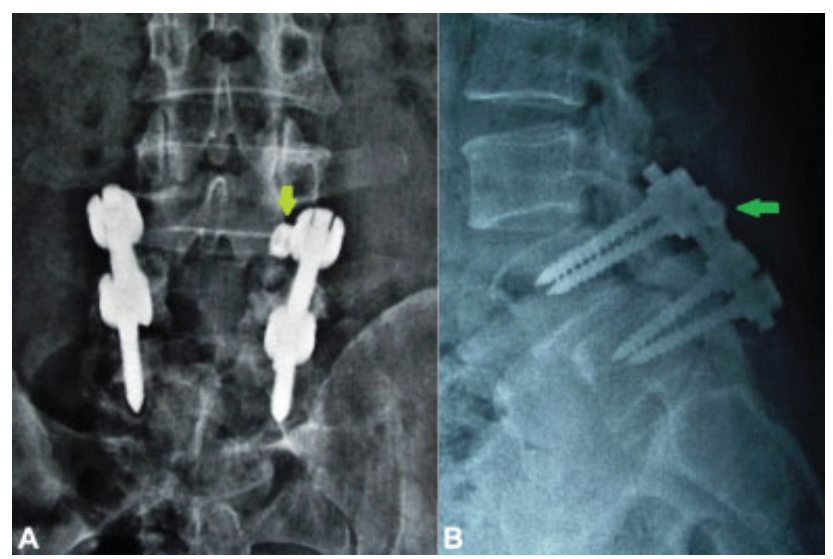

Fig. 1 (A, B) Anteroposterior and lateral skiagrams of the lumbosacral spine showing loosening of the inner nut (green arrows) from the left $L 4$ pedicle screw with implant disassembly. The rod is still lying within the pedicle screw head.
Address for correspondence Prasad Krishnan, MS, MCh, Department of Neurosurgery, National Neurosciences Centre, 2nd Floor, Peerless Hospital Campus, 360, Panchasayar, Garia 700094, Kolkata, West Bengal, India (e-mail: prasad.krishnan@rediffmail.com). resurgery to revise the implant but only the second patient agreed for the same.

Implant disassembly due to pedicle screw nut loosening is a rare complication of spinal instrumentation that predisposes to rod migration with sparse literature mostly in the form of case reports. ${ }^{1-3}$ The inner screw itself, after progressive loosening, may come out of the construct (as in our first case) or may continue to remain in situ (as in our second case). Causes described for screw nut loosening include both insufficient tightening of the inner nut into the pedicle screw head ${ }^{1,3}$ and improper coupling of the inner nut with the pedicle screw head by not squaring the corresponding threads of both the elements prior to tightening. ${ }^{1,3}$ The surgeon must be careful and ensure that there is no soft

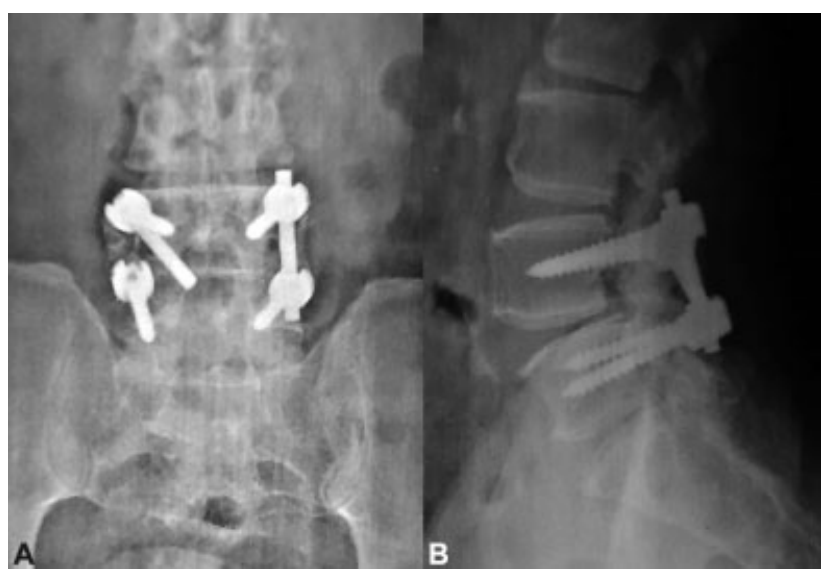

Fig. 2 (A, B) Anteroposterior and lateral skiagrams of the lumbosacral spine showing rod migration medially out of the right $L 5$ pedicle screw head though the inner nut is still lying in situ. published online September 7, 2021
DOI https://doi.org/ 10.1055/s-0041-1735245. ISSN 0976-3147. (c) 2021. Association for Helping Neurosurgical Sick People. All rights reserved.

This is an open access article published by Thieme under the terms of the Creative Commons Attribution-NonDerivative-NonCommercial-License, permitting copying and reproduction so long as the original work is given appropriate credit. Contents may not be used for commercial purposes, or adapted, remixed, transformed or built upon. (https://creativecommons.org/ licenses/by-nc-nd/4.0/)

Thieme Medical and Scientific Publishers Pvt. Ltd., A-12, 2nd Floor, Sector 2, Noida-201301 UP, India 
tissue inside the pedicle screw head at the time of tightening the inner nut and that all nuts are completely tightened after the construct is assembled and also take care that, at the time of insertion, the threads of the inner nut match the grooves on the pedicle screw, a process easily achieved by initially rotating the nut in a counter-clockwise direction till a "click" sound is heard.

\section{Conflict of Interest}

None declared.

\section{References}

1 Agrawal A. Pedicle screw nut loosening: potentially avoidable causes of spine instrumentation failure. Asian Spine J 2014;8(02): 224-226

2 Kumar P, Kumar V, John R, Sharma R. Early loosening of spinal rod in a case of degenerative grade 1 spondylolisthesis treated with unilateral pedicle screw fixation and transforaminal cage for interbody fusion. J Orthop Case Rep 2017;7(04):6-9

3 Agrawal A. Improper coupling between inner nut and screw head leading to rod loosening and dislodgement. Romanian Neurosurgery 2014;21:245-246 